\title{
Stability of Underground Excavation in Porous Limestone: Influence of Water Content
}

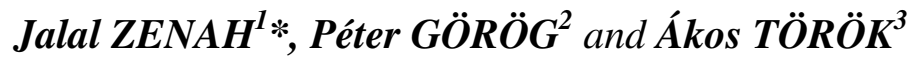

Authors' affiliations and addresses:

${ }^{1}$ Department of Engineering Geology and Geotechnics, Budapest University of Technology and Economics, Budapest, Hungary e-mail: jalal.zenah@epito.bme.hu

${ }^{2}$ Department of Engineering Geology and Geotechnics, Budapest University of Technology and Economics, Budapest, Hungary e-mail: gorog.peter@epito.bme.hu

${ }^{3}$ Department of Engineering Geology and Geotechnics, Budapest University of Technology and Economics, Budapest, Hungary e-mail: torokakos@mail.bme.hu

\section{*Correspondence:}

Jalal Zenah, Department of Engineering Geology and Geotechnics, Budapest University of Technology and Economics, Budapest, Hungary e-mail: jalal.zenah@epito.bme.hu

\section{Acknowledgement:}

The research reported in this paper and carried out at BME has been supported by the NRDI Fund (TKP2020 IES, Grant No. TKP2020 BMEIKA-VIZ) based on the charter of bolster issued by the NRDI Office under the auspices of the Ministry for Innovation and Technology.

How to cite this article:

Zenah, J., Görög, P. and Török, A. (2020). Stability of Underground Excavation in Porous

Limestone: Influence of Water Content. Acta

Montanistica Slovaca, Volume 25 (3), 337-349

DOI:

https://doi.org/10.46544/AMS.v25i3.7

\begin{abstract}
Four different porous limestone lithotypes were collected from the cellar system of Budapest (Hungary). All lithologies have high porosities ranging from 16 to $30 \%$. The laboratory analyses focused on the mechanical properties testing to assess the strength changes due to water saturation. The density, ultrasonic sound wave propagation, uniaxial compressive strength (UCS) and indirect tensile strength (determined by Brazilian test) test were measured on cylindrical specimens according to EN and ASTM standards in the laboratory. Both dry and water-saturated samples were tested. The results indicate that four lithotypes have distinct strength parameters, and both the UCS and the indirect tensile strength decrease with water saturation. The largest decrease in strength was observed at fine-grained porous limestone and at fine- to mediumgrained limestone with a decrease in strength of over 50\%. On the contrary, the strength loss of coarse porous limestone is in the order of 16 to $14 \%$ of UCS and indirect tensile strength, respectively. Comparing the data set of this study with previous works on various limestones, a good correlation was found between density and Brazilian tensile strength. The presented data set was used as the input parameters for calculating the stability of dry and water inundated cellars. The FEM (Finite Element Methods) calculations of cellar stability indicate that the displacement of water-saturated cellars is nearly triple of the dry ones and that the factor of safety reduced from 1.74 in air-dry condition to 1.07 in water-saturated conditions.
\end{abstract}

\section{Keywords}

porous limestone, water saturation, mechanical properties, density, correlation, FEM modelling, factor of safety 


\section{Introduction}

Subsurface openings such as human-made cellars or natural caves are common in urban areas worldwide and can endanger human life and the built environment when these structure collapse (Marschalko et al., 2012). Cellars are known from France (Al Heib et al., 2015; Smeray et al., 2000), Spain (Fuentes et al., 2010), Italy (Ciotoli et al., 2015) and from Hungary (Görög et al., 2013; Vamos et al., 2015; Zenah et al., 2019). The construction period (from Roman times to present) and the excavation methods are different, but in most cases, these structures are cut in rocks without additional support. Different kinds of rocks host these cellars from sedimentary rocks: limestone and sandstone (Görög et al., 2013; Siegesmund et al., 2011; Mocsár-Vámos et al., 2015), to igneous rocks: volcanic tuffs (Aydan and Ulusay, 2003; Kleb and Vásárhelyi, 2003). A similar set of cellars are found in the cities of Hungary, representing various ages from the Middle Age to the 19th century (Gálos et al., 1981). These cellars are found at different depth located close to the surface (Görög et al., 2013; Zenah et al., 2019), or at greater depth (Gálos et al., 1981). The usage of the cellars also varies from agricultural utilisation like wine storage (Fuentes et al., 2010) and mushroom production, or public spaces hosting social and cultural events (for example, restaurants) or even smaller openings that are used as water-sewer systems (Marasović et al., 2014).

Due to the population growth in big cities such as Budapest and intense urbanisation, the extension of the cities in both horizontal and vertical directions is a rapid process. It requires new building sites that might be undercut by cellars. The construction activity causes the additional load, and it is especially risky when cellars are found below the site (Görög et al., 2013; Mocsár-Vámos et al., 2015). In Budapest area, weak rocks, especially porous limestone host most of these cellars (Görög et al., 2013) and are often found below new development areas.

The paper presents the results of the laboratory testing of porous limestone collected from the cellar network of Budapest region and the stability analysis of these human-made cavities due to surface load. It compares mechanical parameters of this Hungarian highly porous limestone with the data published on testing of other limestones worldwide (Bednarik et al., 2014; Ghafoori et al., 2018; Ozguven and Ozcelik, 2013). It emphasises the importance of test conditions and the loss of strength due to water saturation (Vásárhelyi, 2005; Zenah et al., 2019). These are key issues since the stability of these subsurface openings strongly depend on the mechanical parameters of the host rock. Namely, when there is a significant loss in strength due to extrinsic factors occurs, there is a high risk of collapse and surface subsidence. For the calculation of stability and safety factors of subsurface openings (caves, mines, and cellars) physical parameters of the host rock are essential (Görög et al., 2013). The obtained mechanical data was used to calculate the stresses around cellars and subsurface openings that were cut in porous limestone. In the investigation area, there are used and unused cellars, while the used cellars are ventilated, and the changes in the rock mass quality can be easily detected. The unused cellars have many times no ventilation and only rarely supervised, which can cause wet rock surfaces. Therefore, the modelling of the effect of water is essential. Near stability analysis, the different processes such as mining processes (Janič et al., 2019), weathering processes of the rock masses can be simulated (Ghabezloo and Pouya, 2006). The FEM calculation in this study tried to determine the effect of water on the stability of the cellars due to surface loading.

\section{Materials}

The studied Hungarian limestone is porous (Rozgonyi, 2002) that was formed during the Miocene period. The limestone is considered as a shallow marine subtropical carbonate deposited in the Pannonian Basin. It covers larger areas in and around Budapest (Vásárhelyi, 2005). It was used as a construction material for centuries, and emblematic buildings of Budapest, such as the Parliament building, Citadella fortress or Mathias Church was built from this stone (Török et al., 2007). Miocene limestone was used not only in Hungary, but it is one of the most common building stones in Central Europe. Examples of buildings and structures are known from Austria (St. Stephan's Church, Vienna) and Slovakia (Bednarik et al., 2014; Laho et al., 2010), from Czech Republic (Valtice) also (Přikryl and Přikrylová, 2004; Török et al., 2004). Besides Central Europe, similar stones are known from Belgium (De Kock et al., 2017), from France (Beck and Al-Mukhtar, 2008; Gibeaux et al., 2018; Hassine et al., 2018) and from the Mediterranean Region of Italy (Pappalardo et al., 2016), Cyprus (Modestou et al., 2016) and Malta (Cassar, 2002). Less porous limestones are also known worldwide (Zhang et al., 2017) and have been used to construct buildings (Smith et al., 2010) and bridges (Ademović and Kurtović, 2018).

The stone was popular since it is highly porous and easy to work with. Therefore, it became one of the key construction material of the 18th and 19th century (Pápay and Török, 2017). Durable varieties of limestone were also used for bridge construction such as the limestone bridge in Mostar, Bosnia and Herzegovina (Čorko et al., 2001). 
The tested porous Miocene limestone is known to be a soft rock with high and variable porosity $(14-52 \%)$, and consequently, a wide variation in the petrophysical properties was observed (Vásárhelyi, 2005; Zenah et al., 2019). Its textural variety was also discussed in previous studies (Pápay and Török, 2017; Török et al., 2007).

Laboratory tests were realised on the stone blocks obtained from cellars of Budapest city located at Buda side of the city (Fig. 1a, 1b). The cellar system has large openings that are currently used for mushroom cultivation (Fig. 1c, 1d). The studied porous limestone blocks were described in details, and the samples were divided into four different lithologies: numbered from I to IV.

Type I. Fine-grained porous limestone. It has a few gastropods that form moldic pores. Its micro-fabric is characterised by very fine carbonate grains with very small pores. Its colour is white, slightly yellowish stain (Fig. 2I).

Type II. Coarse-grained ooidal porous limestone. It is characterised by fine sand-sized, well-rounded ooids and has a rough surface with larger but regularly arranged pores. Small grey quartz sand particles are also observed in this lithotype and broken bioclasts of less than $0.5 \mathrm{~cm}$ in size (Fig. 2II).

Type III. Fine- to medium-grained porous limestone. It has a non-uniform microfabric since mediumgrained carbonate particles form irregular patches within the fine-grained, porous limestone. Its fine-grained parts are coarser than that of Type I, and it contains more bioclasts (Fig. 2III).

Type IV. Cross-laminated fine- and medium-grained porous limestone. The lithotype is not uniform even in a tests specimen scale; it is visible that it contains fine-grained and medium-grained parts that are alternating and show cross lamination (Fig. 2IV).

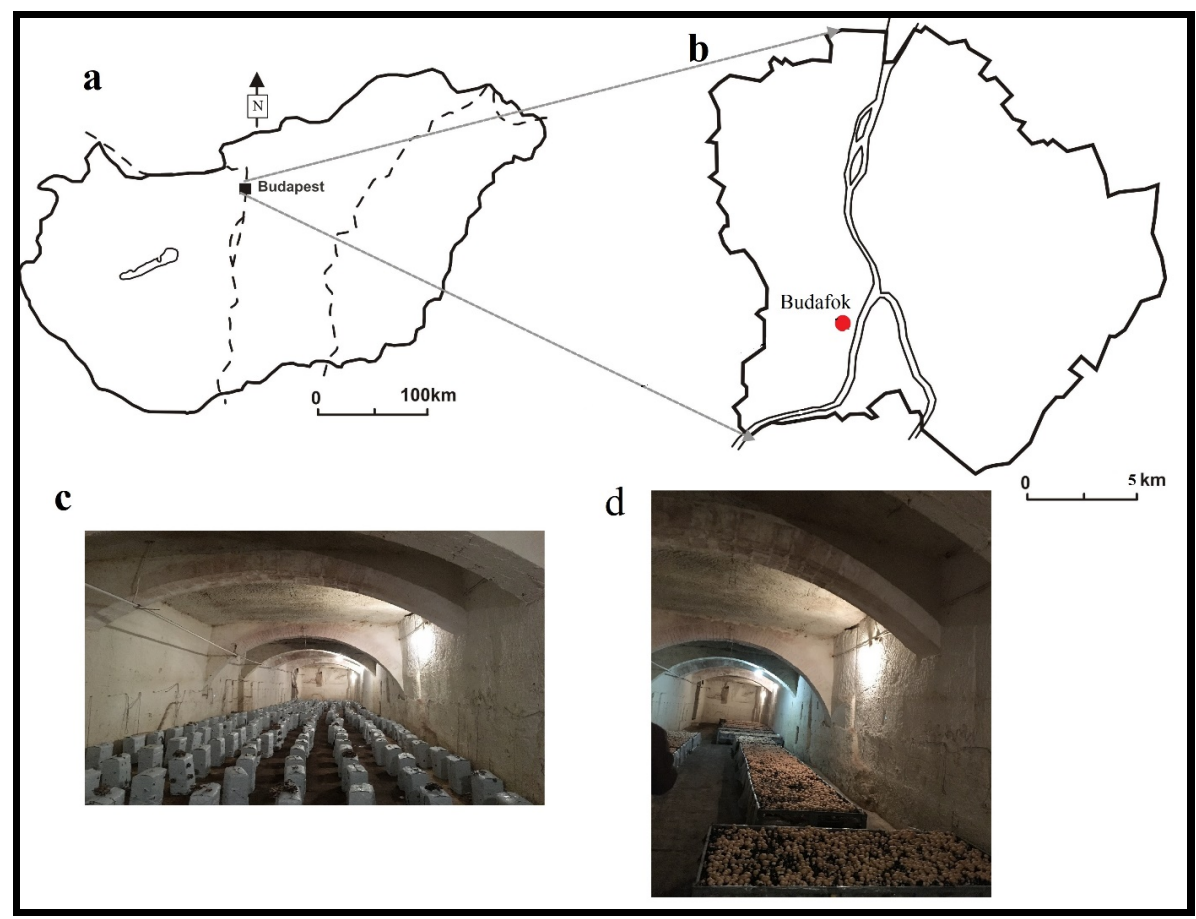

Fig. 1. Map of Hungary (a) with the location of the studied cellar system in Budapest city (b). The cellar was cut into porous limestone and has large spacing, that is currently used for mushroom cultivation $(c, d)$.
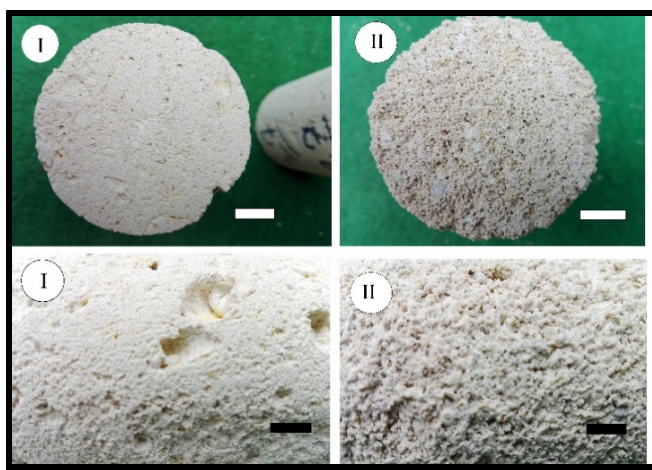
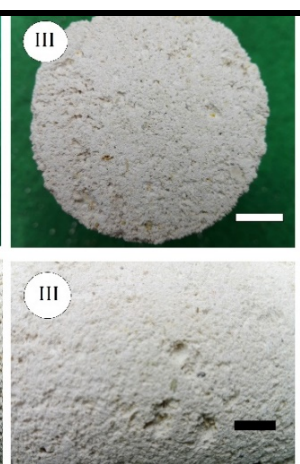

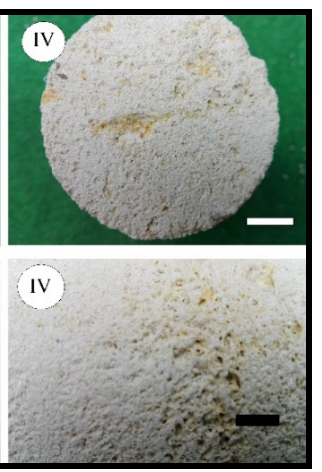

Fig. 2. Textural characteristics of the studied lithotypes (numbered I to IV), scale bar is $1 \mathrm{~cm}$. Their detailed lithological description is in the text. 


\section{Methods}

Cylindrical specimens were drilled $(50 \mathrm{~mm}$ in diameter) from the limestone blocks by using the core drilling apparatus in the laboratory. The cores were cut to two sets of sample sizes according to their height (length-L, diameter-D): for Brazilian tests with $\mathrm{L} / \mathrm{D} \approx 1$, and for uniaxial compressive strength tests (UCS) with $\mathrm{L} / \mathrm{D}$ in a range from 1.45 to 1.93 . In the calculation of UCS, the correction of these values to $\mathrm{L} / \mathrm{D}=2$ was made. The surface of all test specimens was ground to get parallel plane surfaces for uniform stress distribution.

Tests were made according to EN and ASTM guidelines. Dry and saturated apparent densities were determined according to (EN 1936:2006). The uniaxial compressive strength (UCS) tests and Brazilian tests for both dry and saturated conditions were made according to ASTM D7012-14e1 and ASTM D 3967-16, respectively. The water absorption test (EN 13755:2008) was aimed to assess and compare the open porosity and water uptake of different lithologies. Capillary water absorption was detected based on the measurement of the masses of specimens after $15 \mathrm{sec}$ in regular intervals till four days. Water absorption capillary curves were also drawn based on test results. The ultrasonic wave velocity tests were performed on cylindrical test specimens (EN 14579:2004) to analyse internal structure (possibility of micro-cracks) of the rock specimens by measuring wave velocities in $\mathrm{km} / \mathrm{sec}$. Altogether 132 specimens were tested in the laboratory (Tab. 1).

Tab. 1. Test methods and number of tested specimens

\begin{tabular}{|c|c|c|c|}
\hline Tab. 1. Test methods and number of tested specimens \\
\hline \multirow{2}{*}{ Property } & \multirow{2}{*}{ Code of the test procedure } & \multicolumn{2}{c|}{ Number of specimens } \\
\cline { 3 - 4 } & & Dry & Saturated \\
\hline Density & EN 1936:2006 & 132 & 132 \\
\hline US-wave velocity & EN 14579:2004 & 132 & 132 \\
\hline UCS & ASTM D7012-14e1 & 31 & 25 \\
\hline Brazilian strength & ASTM D3967-16 & 31 & 26 \\
\hline Water absorption & EN 13755:2008 & \multicolumn{2}{|c}{9} \\
\hline Capillary water absorption & EN 1925:1999 & \multicolumn{2}{|c}{} \\
\hline
\end{tabular}

The geometry of the cellar was determined by terrestrial laser scanning (TLS), we used a phase-based terrestrial laser scanner (Faro Focus 120S) with $+/-2 \mathrm{~mm}$ ranging accuracy and $120 \mathrm{~m}$ maximum measurement range.

The stability calculations have been performed by the Rocscience software package, with the RS2 2019 finite elements code. The used software is a hybrid finite element code, which makes possible the slipping through joints elements. They can apply the Hoek-Brown material model, so in the modelling, the input parameters of the modelling programs are: UCS determine in the laboratory as in (Tab.2) and (Tab.3), Young modulus calculated after the analysis of the lab result (from the stress-strain graph), Hoek-Brown constant (mi) is calculated based on a lab result, and also it can be calculated by RocLab program (which analyse the laboratory data, or simply we choose the rock type in the program, and the program will give the value based on the saved table), and geotechnical strength index for the rock mass (GSI) determined by fieldwork.

According to these values, the software calculates the Hoek-Brown parameters of the rock masses (Hoek et al., 2002).

\section{Results}

\section{Laboratory Tests results}

The apparent porosity of tested porous limestone has a range of $10.5 \%$ to $17.7 \%$, which was calculated from mass changes as a function of time during capillary water absorption tests (Fig. 3). The absorption curves have very similar shapes; however, the rate of water absorption and time of full capillary suction saturation slightly differs. The highest water uptake was observed at Type I lithotype, which has the finest grain size and smallest pore-sizes The lowest water absorption was measured at specimens of Type IV, where the micro-fabric is heterogeneous.

The open porosity of the lithotypes can be calculated based on the dry apparent density and saturated apparent density. The latter one was measured on fully saturated test specimens that were submerged into the water until full saturation (maximum weight) was obtained. The densities (dry and saturated) as well as strength parameters of dry and water-saturated test specimens with a minimum, maximum values and averages are given in Tab. 2 and Tab. 3. The wide range of the results marks the heterogeneity of the lithotypes. 


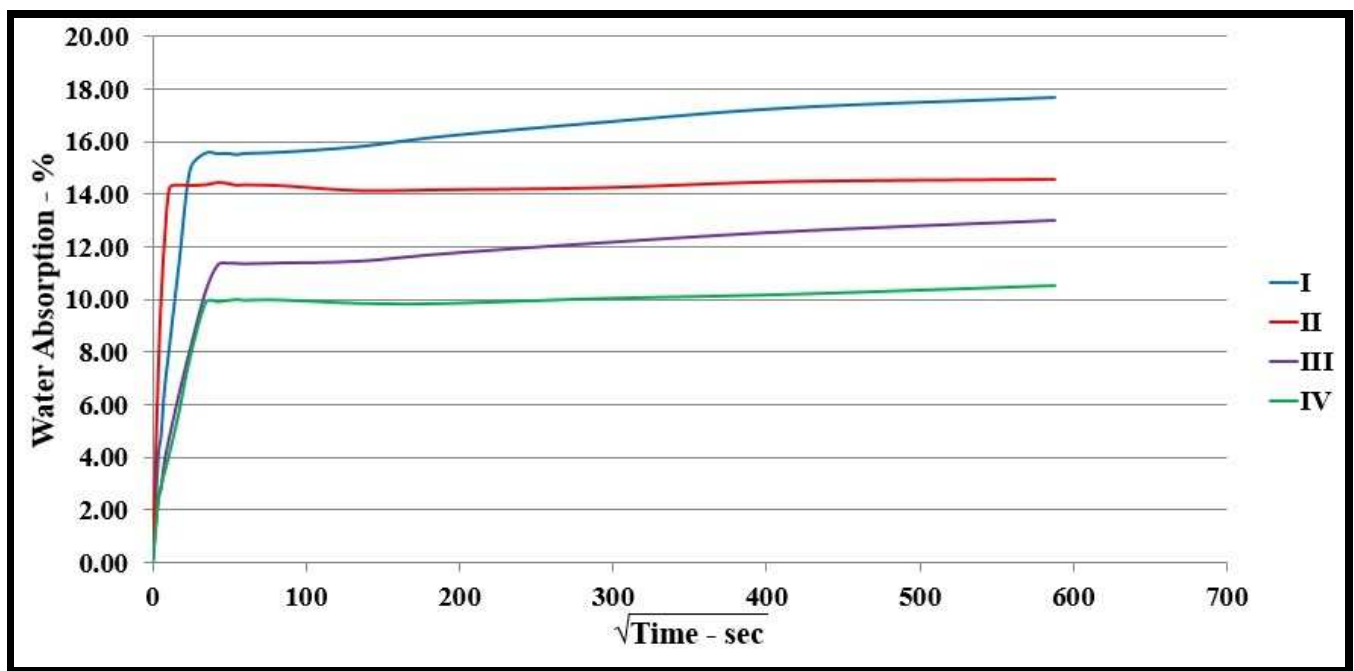

Fig. 3. The capillary water absorption curves of porous limestone Types I-IV

Tab. 2. Test results of dry specimens

\begin{tabular}{|c|c|c|c|c|c|c|c|c|c|}
\hline & \multicolumn{3}{|c|}{ Dry Density [gr/cm ${ }^{3}$ ] } & \multicolumn{3}{c|}{ Dry UCS [MPa] } & \multicolumn{3}{c|}{$\begin{array}{c}\text { Dry Brazilian tensile } \\
\text { strength [MPa] }\end{array}$} \\
\cline { 2 - 11 } & $\min$ & $\max$ & $\operatorname{mean}$ & $\min$ & $\max$ & $\operatorname{mean}$ & $\min$ & $\max$ & $\operatorname{mean}$ \\
\hline Type I & 1.51 & 1.62 & 1.57 & 7.90 & 15.86 & 10.95 & 0.18 & 1.08 & 0.58 \\
\hline Type II & 1.52 & 1.71 & 1.62 & 2.16 & 13.40 & 9.57 & 1.03 & 2.11 & 1.56 \\
\hline Type III & 1.74 & 1.85 & 1.80 & 15.40 & 27.77 & 22.74 & 1.59 & 4.65 & 3.22 \\
\hline Type IV & 1.65 & 1.84 & 1.77 & 8.43 & 26.56 & 15.12 & 0.76 & 2.05 & 1.16 \\
\hline
\end{tabular}

Tab. 3. Test results of water-saturated specimens

\begin{tabular}{|c|c|c|c|c|c|c|c|c|c|}
\hline & \multicolumn{3}{|c|}{ Sat Density [gr/cm ${ }^{3}$ ] } & \multicolumn{3}{c|}{ Sat UCS [MPa] } & \multicolumn{3}{c|}{$\begin{array}{c}\text { Dry Brazilian tensile } \\
\text { strength [MPa] }\end{array}$} \\
\cline { 2 - 11 } & $\min$ & $\max$ & mean & $\min$ & $\max$ & mean & min & max & mean \\
\hline Type I & 1.81 & 1.84 & 1.88 & 2.85 & 7.04 & 5.16 & 0.07 & 0.39 & 0.26 \\
\hline Type II & 1.79 & 1.87 & 1.95 & 3.49 & 12.54 & 8.06 & 1.08 & 1.82 & 1.35 \\
\hline Type III & 1.96 & 2.02 & 2.07 & 5.10 & 14.57 & 10.59 & 0.91 & 1.42 & 1.29 \\
\hline Type IV & 1.84 & 1.97 & 2.06 & 7.27 & 17.38 & 11.91 & 0.67 & 1.17 & 0.89 \\
\hline
\end{tabular}

Densities are plotted in (Fig. 4). The relations between the two measured parameters are generally very strong, and the correlation coefficient is between 0.5367 and 0.981 (Fig. 4). The highest correlation was found for Type II, while the lowest for Type I, respectively. The equations and the correlation coefficients are given in (Tab. 4).

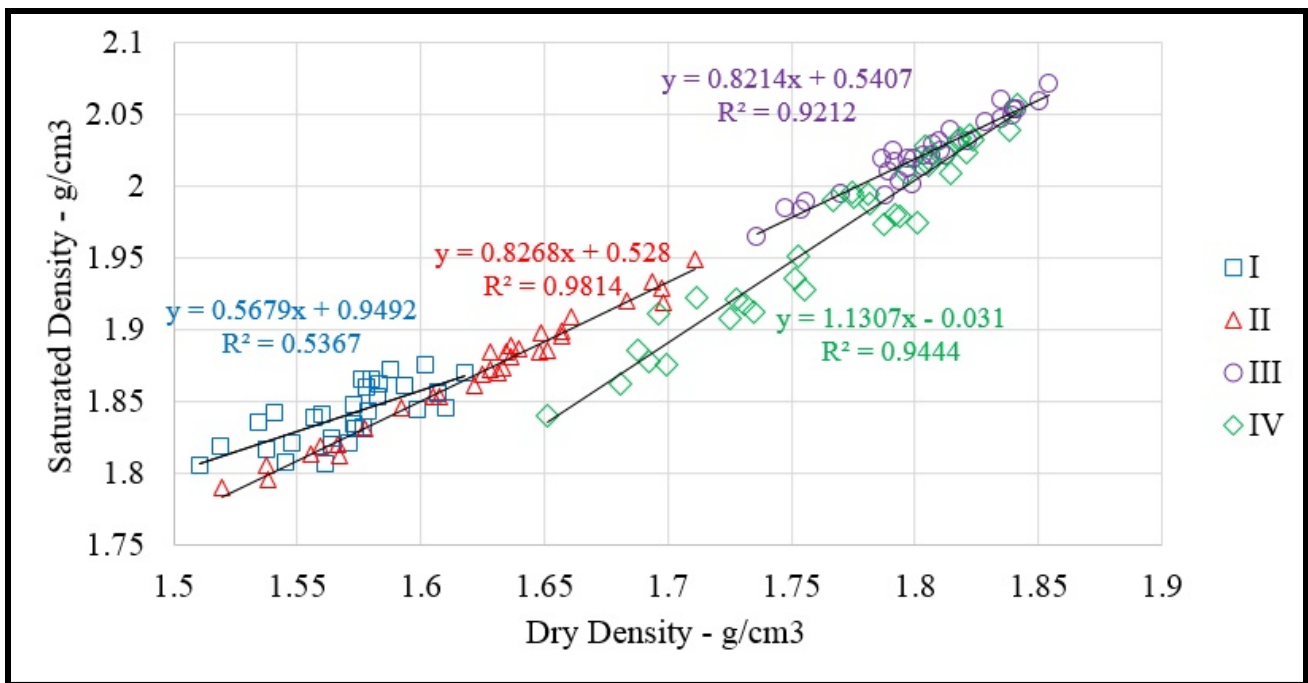

Fig. 4. Relationship between dry and saturated densities of rock Types I-IV 
Tab. 4. Calculated relationships between dry and saturated densities of rock Types I-IV

\begin{tabular}{|c|c|c|}
\hline Type & Equations & R2 \\
\hline I & $Y=0.5679 * X+0.9492$ & 0.5367 \\
\hline II & $Y=0.8268 * X+0.528$ & 0.9814 \\
\hline III & $Y=0.8214 * X+0.5407$ & 0.9212 \\
\hline IV & $Y=1.1307 * X-0.031$ & 0.9444 \\
\hline
\end{tabular}

The relationship between apparent density and ultrasonic waves (US waves) velocity cannot be described with one equation, (Fig. 5). The various lithotypes from distinct groups of data, and the shift of data set toward higher values of densities are clear, but in terms of US-wave velocity, the changes are not so uniform (Fig. 5).

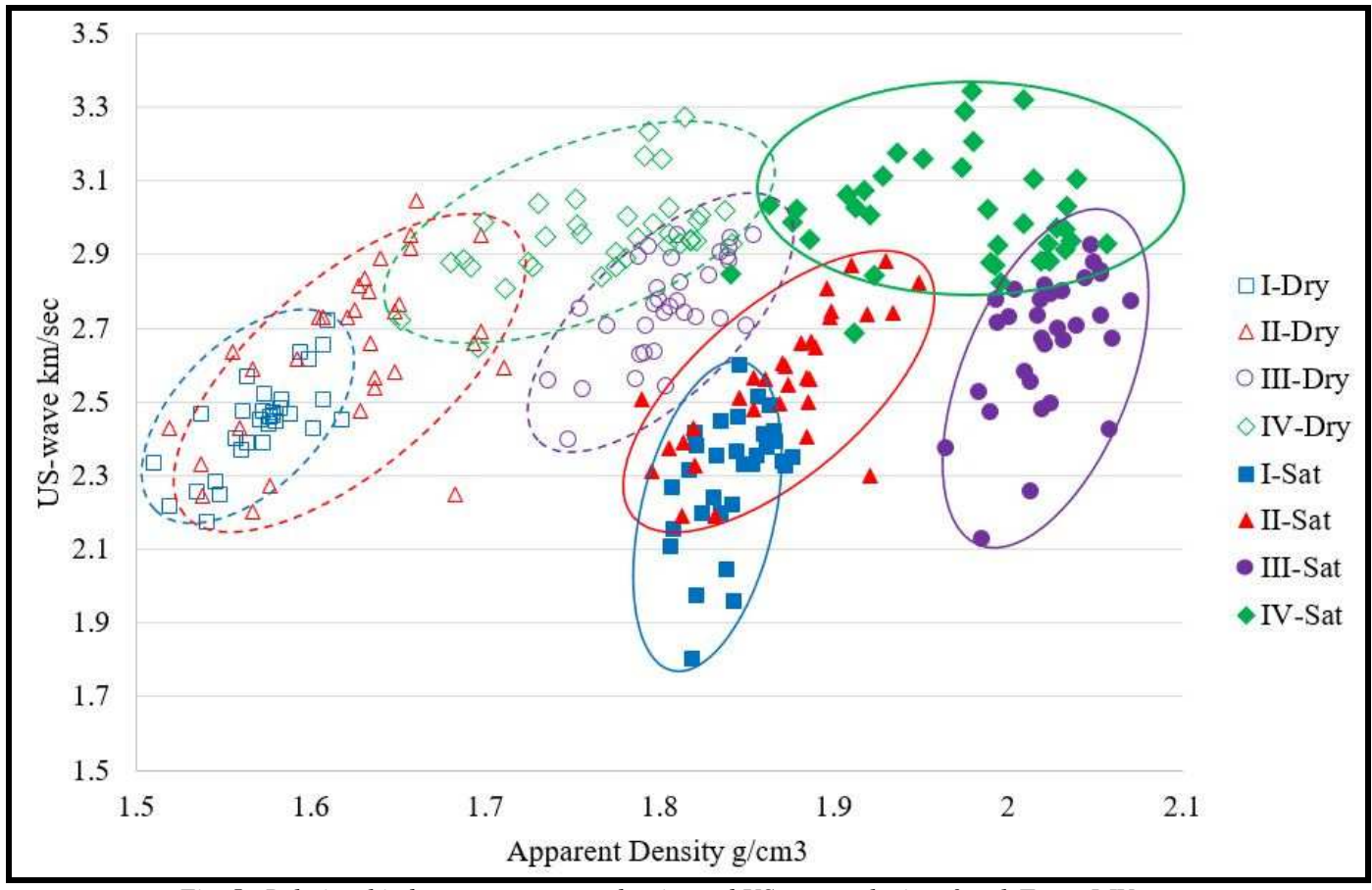

Fig. 5. Relationship between apparent density and US wave velocity of rock Types I-IV

According to the measured values, there is a good linear relationship between ultrasonic waves and open porosity in both dry and saturated conditions (Fig. 6). The differences between dry and saturated samples are marked by dashed (dry) and continuous lines, and it seems that the distinction of the two test conditions are not very easy, since there are some overlaps between the fields (Fig. 6).

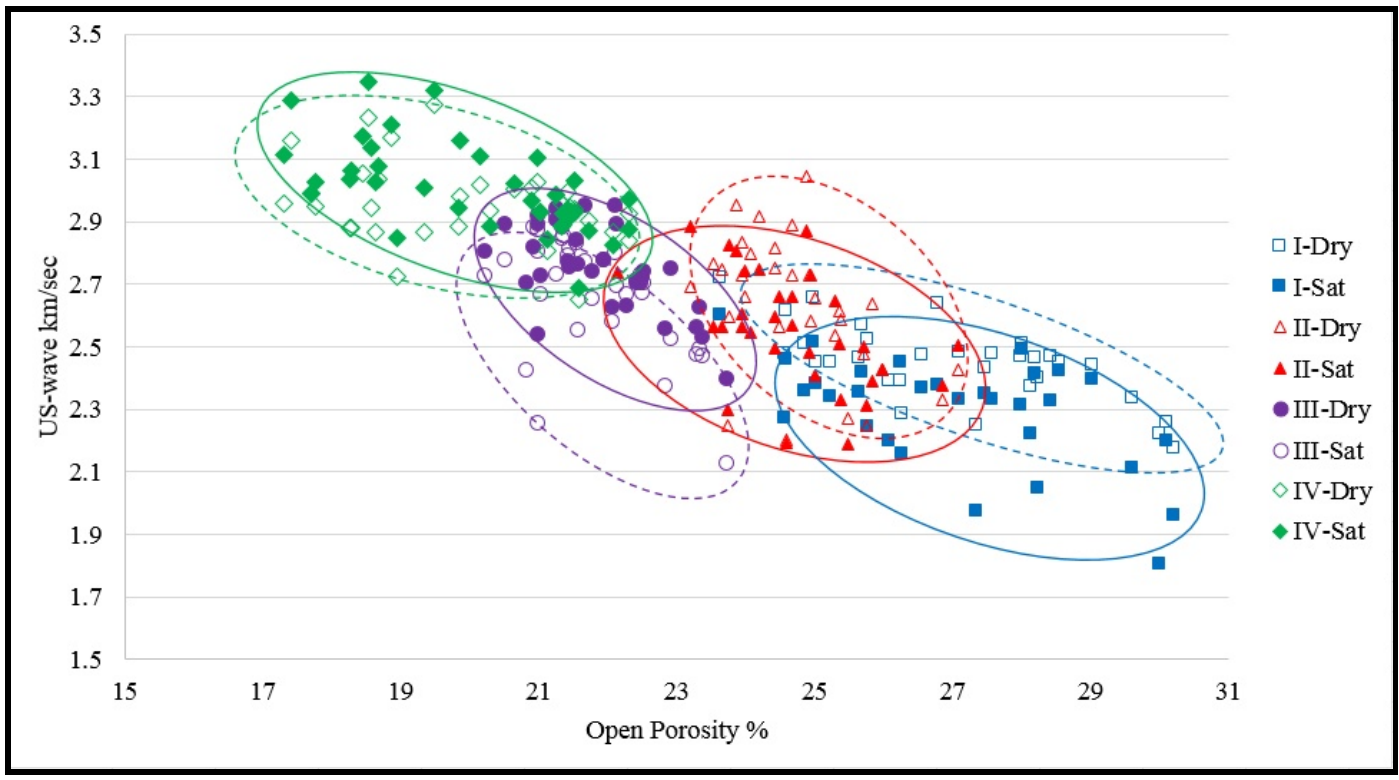

Fig. 6. Relationship between open porosity and US wave velocity of rock Types I-IV 
The relation between density and UCS was plotted in both dry and saturated conditions (Fig. 7). The results are clearly divided into four distinct groups. Two sets of dry and two sets of water-saturated samples are marked on (Fig. 7). In the lowest range, the dry specimens of Type I + Type II are found, which is followed by dry specimens of Type III + Type IV, and water-saturated specimens of Type I + Type II, and water-saturated specimens of Type III + Type IV, respectively (Fig. 7).

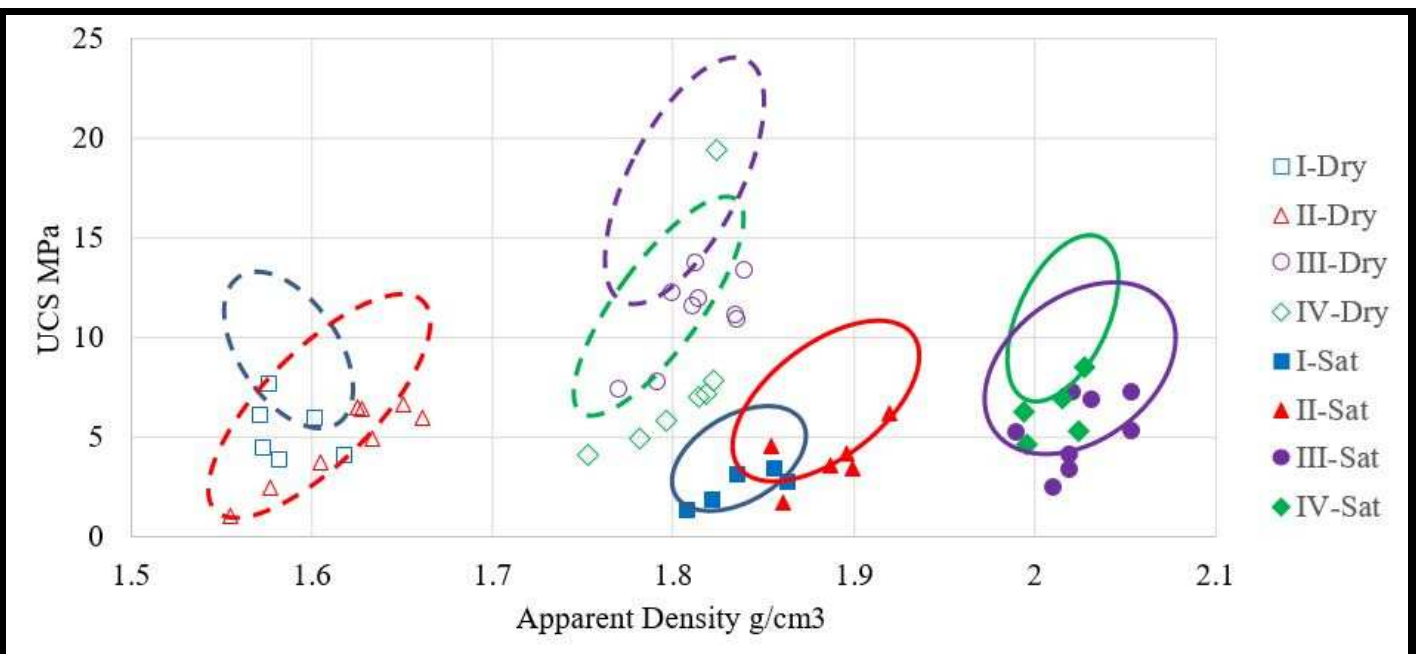

Fig. 7. Relationship between UCS and apparent density of rock Types I-IV (ranges of dry and saturated samples are marked by continuous and dashed lines, respectively)

A reduction of UCS and tensile strength tests due to water saturation was also determined. The loss in strength is not uniform. The highest reduction was measured at limestone Type III (over 50\%), which is followed by specimens of Type I, while the least reduction was documented at Type II (Tab. 5). Thus the most sensitive group to water is Type III, while the least sensitive one is Type II with strength loss of $16 \%$ and $14 \%$ in UCS and in indirect tensile strength, respectively.

Tab. 5. Reduction of strength due to water saturation

\begin{tabular}{|c|c|c|c|c|c|c|}
\hline \multirow[b]{2}{*}{ Type } & \multicolumn{3}{|c|}{ UCS, mean value } & \multicolumn{3}{|c|}{ Tensile strength, mean value } \\
\hline & $\begin{array}{c}\text { Dry } \\
\text { Condition } \\
{[\mathrm{Mpa}]}\end{array}$ & $\begin{array}{c}\text { Saturated } \\
\text { Condition } \\
\text { [Mpa] }\end{array}$ & Loss in strength [\%] & $\begin{array}{c}\text { Dry Condition } \\
{[\mathrm{Mpa}]}\end{array}$ & $\begin{array}{c}\text { Saturated } \\
\text { Condition } \\
\text { [Mpa] }\end{array}$ & Loss in strength [\%] \\
\hline II & 9.57 & 8.06 & 15.78 & 1.56 & 1.35 & 13.46 \\
\hline III & 22.74 & 10.59 & 53.43 & 3.22 & 1.29 & 59.94 \\
\hline
\end{tabular}

\section{Stability analysis Results}

The 3D geometry of the investigated part of the cellar system is in (Fig. 8). The 2D section, where stability analyses were made, is $10 \mathrm{~m}$ from the main corridor of the cellar system as it is shown in the (Fig.8).

The thickness of the cover layers above the cellar system is around $5 \mathrm{~m}$ measured through ventilation shafts. The model contains two layers the weathered and jointed above the layer of the porous limestone, and the rest of them, which is massive with only some joints. The input parameters of the calculations are from Tab. 2. The samples are from the investigated cellar system, but the spatial arrangement of the lithotypes in the cellar are varied and difficult to include this variation in the model. Therefore, the minimum strength parameters of the porous limestone types were used in the model (Tab.2, Tab.3). In dry condition: UCS $=2.1 \mathrm{MPa}, E=4110 \mathrm{MPa}$, $m_{i}=10, G S I=80$. Above the surface, $500 \mathrm{kN} / \mathrm{m}^{2}$ load was applied to consider further building improvements. 


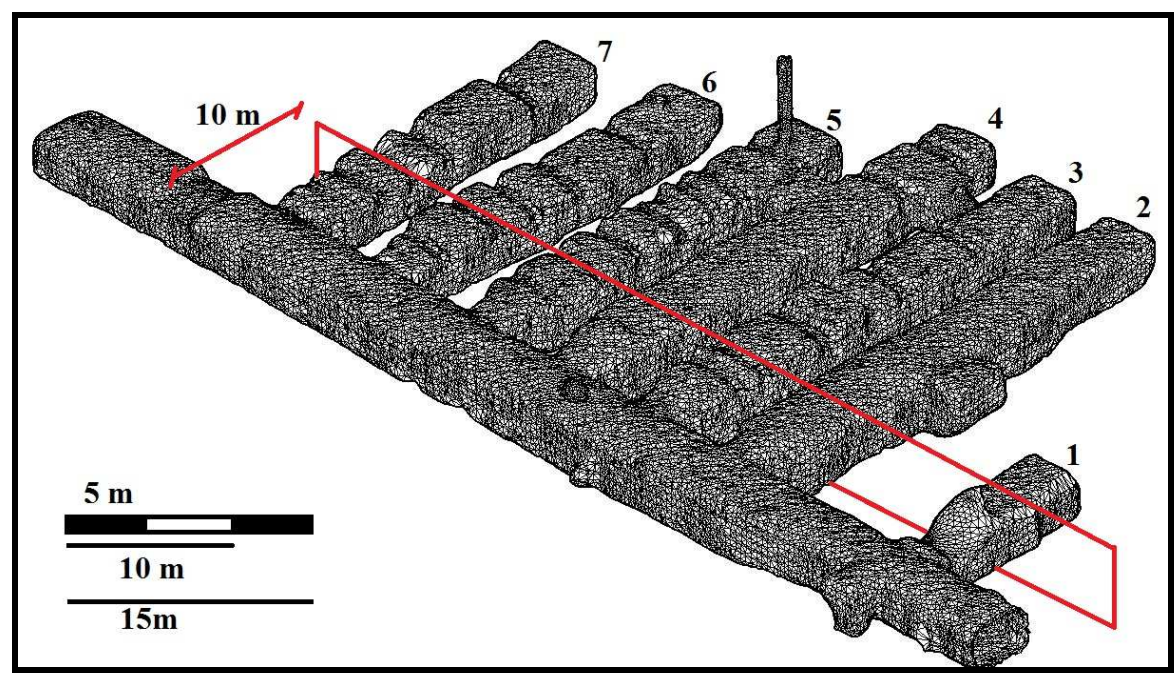

Fig. 8. $3 D$ view of the investigated part of the cellar system, the geometries were obtained by TLS, red line shows the place of the modelled cross-section.

The (Fig. 9). shows the total displacements of the calculated sections, both dry and water-saturated conditions, the increasing displacements are signed with warm colours (yellow, orange and red). The red zone above the 2. and 3. cellar branches at the top figure shows the highest displacements. The place of the highest displacements depends on the cover above the cellar branches and the width of the pillar between the branches. There are only a few joints in the cellar since the rock mass of the porous limestone is massive, but the model contains these few joints. The effects of the joints to the displacements are given in (Fig. 9), which shows slightly different displacement at different sides of the joints.

The value of displacements of the different cellar branches between dried and water-saturated conditions is in (Fig. 10). Under water-saturated conditions, the displacements were almost three times higher compared to dry conditions. The safety factor was also reduced because of the water-saturated condition from (1.74) in airdry condition down to (1.07) in water-saturated conditions.

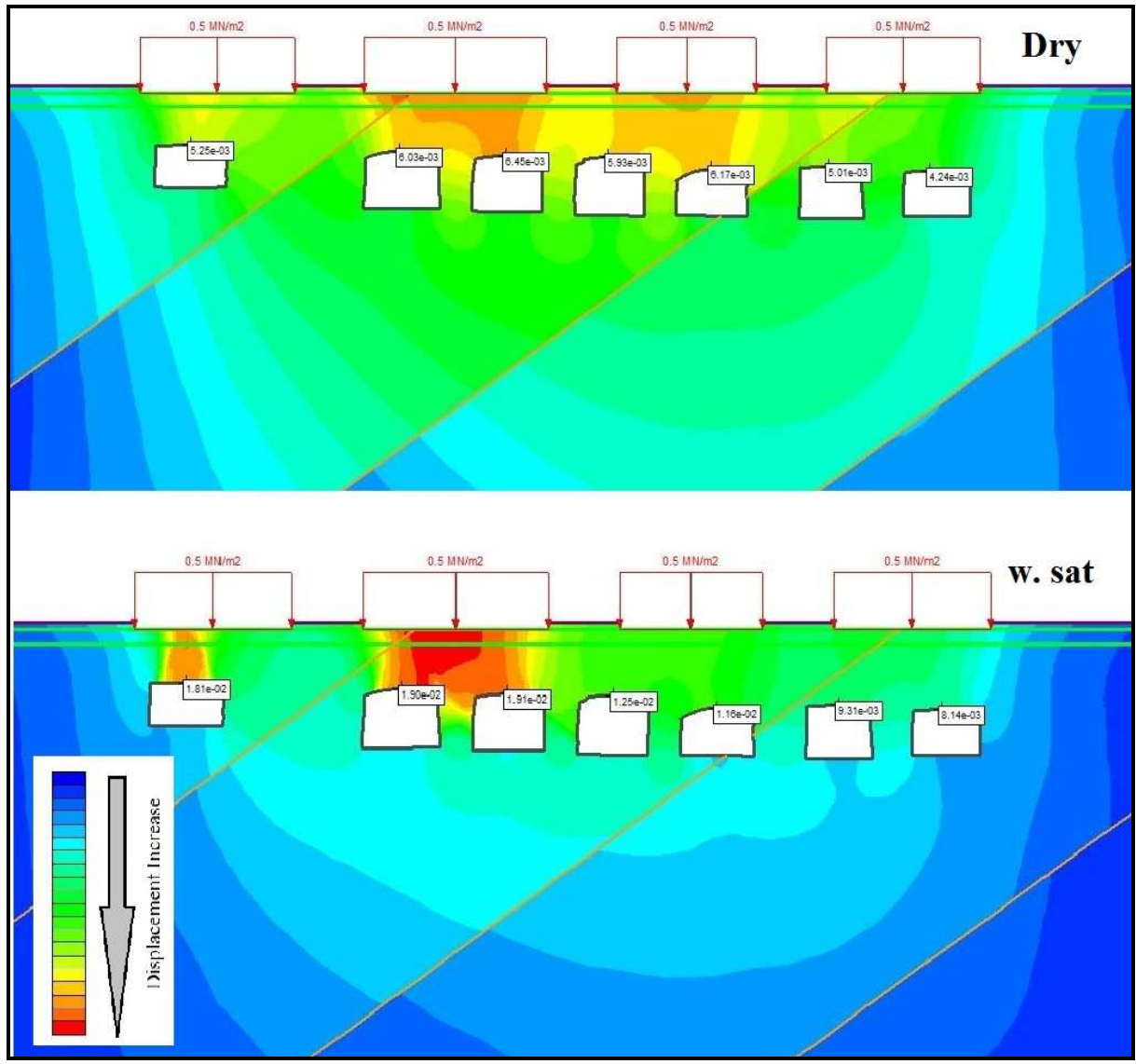

Fig. 9. Total displacements of the calculated sections both dry and water-saturated conditions 


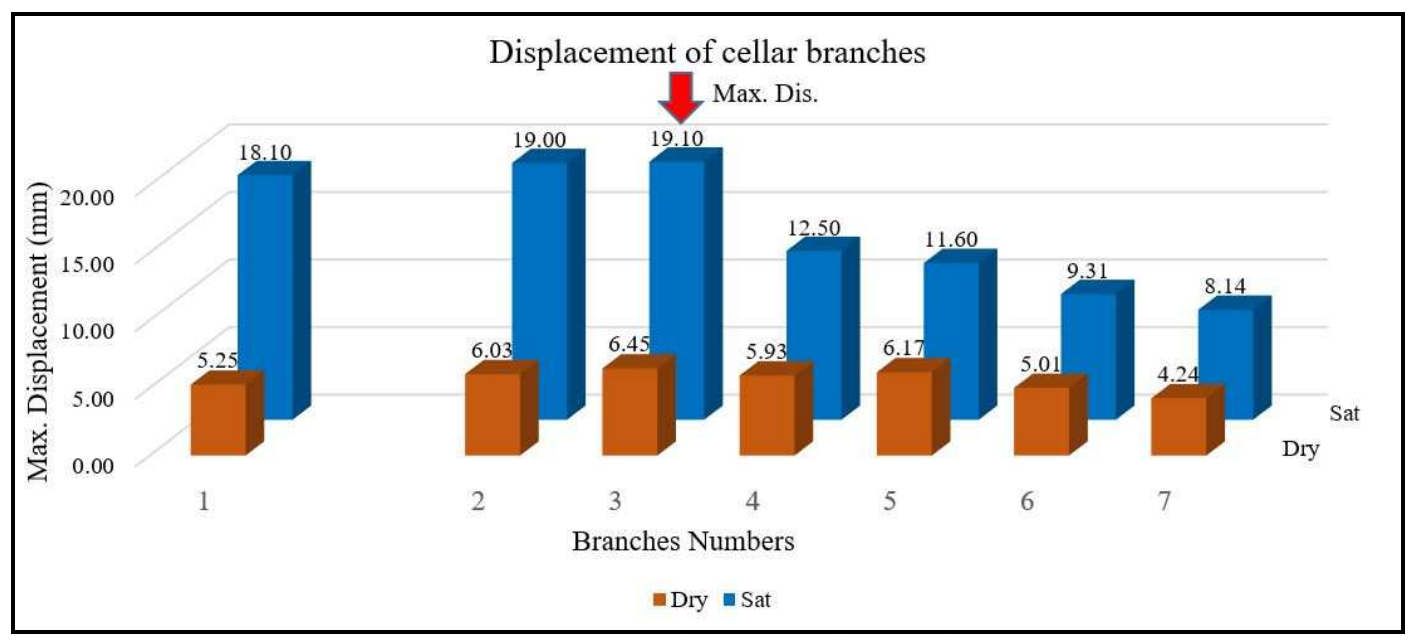

Fig. 10. Displacements of the different cellar branches

\section{Discussion}

The test results of the four lithotypes (Type I-IV) are compared to data on various limestone types published previously (Tab. 6). The comparison includes the physical parameters such as density, uniaxial compressive and indirect tensile strength. As shown in the (Tab. 6), the Miocene limestone from Budafok has a relative low UCS compared to the low porosity limestones of Jordan (Dweirj et al., 2017) or Turkey (Aydan and Ulusay, 2003). The loss in the UCS due to water saturation is much higher at the Miocene limestone presented in this paper than that of the Jordanian limestone (Dweirj et al., 2017) (Tab. 6), which strength reduction is except for Zarka limestone is less than $50 \%$. The Brazilian strength test results of this paper demonstrate the sensitivity of this limestone types to water saturation. An even higher strength reduction in tensile strength was measured at Zarka limestone (Dweirj et al., 2017) (Tab. 6).

Previous studies dealing with the effect of water on the strength of porous limestone suggest that there is a significant loss in strength due to water saturation (Vásárhelyi, 2005; Zenah et al., 2019). The accidental water saturation or flooding of subsurface openings and mines can also cause significant problems such as sliding or loss of stability (Polak et al., 2015). It was also noted that not only water but freeze-thaw action also reduces the strength of this porous Hungarian limestone (Pápay and Török, 2017). Considering all these previous observations it is necessary to note that important input parameters for the stability calculation of cellar systems are strength parameters (Görög et al., 2013; Zenah et al., 2019). Thus this observed sensitivity to water clearly controls the stability of the studied cellar system, namely water saturation or accidental water inundation of cellars might cause a collapse of the formerly stabile cellar system due to drastic loss in strength of the porous limestone.

To assess strength parameters with measuring only the density of limestone is possible (Vásárhelyi, 2005) since there is a correlation between density and strength. It has also been noted that porosity and micro-fabric strongly influence the durability of such limestones (Scrivano et al., 2018; Török et al., 2007). In the studied samples Type I has the highest open porosity with the highest water absorption (Fig. 3). Namely, this lithotype has the highest amount of open pores that can have a negative effect on the loss in strength due to water saturation (Scrivano et al., 2018). Our results partly confirm this assumption since a high loss in strength (over $50 \%$ ) was measured on saturated water specimens compared to dry ones (Tab. 5). However, the other lithotype that is more sensitive to water saturation (Type III), where the loss of strength is larger (Tab. 5), has lower porosity and lower water absorption (Fig. 3). Here, the higher loss in strength is probably attributed to the poresize distribution differences, namely more diverse pores. This feature, the role of pore-size distribution in the durability and strength loss was already suggested in previous works (Hassine et al., 2018; Pápay and Török, 2017; Přikryl, 2013; Török et al., 2007). The strength and durability of carbonate rocks are negatively influenced by the clay content, especially when the carbonates (marls) are subjected to cyclic wetting and drying (Vlastelica et al., 2017).

When Brazilian strength and density of the studied limestone (Type I-IV) are compared with previous works a fairly good correlation was found, although the data sets of different limestone types were plotted at various fields in the graph (Fig. 11). It suggests that density is a good indicator of limestone strength, similarly to previously published data (Martínez-Martínez et al., 2013; Török and Vásárhelyi, 2010; Vásárhelyi, 2005). 
Tab. 6. Physical parameters of limestone, comparative data set from previous work and this study

\begin{tabular}{|c|c|c|c|c|c|c|c|}
\hline \multirow{2}{*}{ Place } & \multicolumn{2}{|c|}{$\begin{array}{l}\text { Density } \\
{\left[\mathrm{kg} / \mathrm{m}^{3}\right]}\end{array}$} & \multicolumn{2}{|c|}{$\begin{array}{l}\text { UCS } \\
\mathrm{MPa}\end{array}$} & \multicolumn{2}{|c|}{$\begin{array}{l}\text { Brazilian tensile strength } \\
\qquad \mathrm{MPa}\end{array}$} & \multirow[t]{2}{*}{ References } \\
\hline & Dry & Sat & Dry & Sat & Dry & Sat & \\
\hline $\begin{array}{c}\text { Budafok - Type I } \\
\text { - Hungary }\end{array}$ & $\begin{array}{c}1510- \\
1620\end{array}$ & $\begin{array}{c}1810- \\
1840\end{array}$ & $\begin{array}{l}7.91- \\
15.86\end{array}$ & $2.85-7.04$ & $0.18-1.08$ & $\begin{array}{c}0.07- \\
0.39\end{array}$ & this study \\
\hline $\begin{array}{c}\text { Budafok - Type } \\
\text { II - Hungary }\end{array}$ & $\begin{array}{c}1520- \\
1710\end{array}$ & $\begin{array}{c}1790- \\
1870\end{array}$ & $\begin{array}{l}2.16- \\
13.40\end{array}$ & $3.49-12.54$ & $1.03-2.11$ & $\begin{array}{c}1.08- \\
1.82\end{array}$ & this study \\
\hline $\begin{array}{l}\text { Budafok - Type } \\
\text { III - Hungary }\end{array}$ & $\begin{array}{c}1740- \\
1850\end{array}$ & $\begin{array}{c}1960- \\
2020\end{array}$ & $\begin{array}{l}15.40- \\
27.77\end{array}$ & $5.10-14.57$ & $1.59-4.65$ & $\begin{array}{c}0.91- \\
1.42\end{array}$ & this study \\
\hline $\begin{array}{l}\text { Budafok - Type } \\
\text { IV - Hungary }\end{array}$ & $\begin{array}{c}1650- \\
1840\end{array}$ & $\begin{array}{c}1840- \\
1970\end{array}$ & $\begin{array}{l}8.43- \\
26.56 \\
\end{array}$ & $7.27-17.38$ & $0.76-2.05$ & $\begin{array}{c}0.67- \\
1.17 \\
\end{array}$ & this study \\
\hline $\begin{array}{l}\text { Sóskút - } \\
\text { Hungary }\end{array}$ & $\begin{array}{l}1360- \\
2410\end{array}$ & $1720-2460$ & $0.86-38.8$ & $0.63-27.6$ & $0.07-4.16$ & $\begin{array}{c}0.08- \\
3.99\end{array}$ & (Vásárhelyi, 2005) \\
\hline Asmari - Iran & $\begin{array}{c}2130- \\
2570 \\
\end{array}$ & & $\begin{array}{c}5.48- \\
109.03 \\
\end{array}$ & & & & (Ghafoori et al., 2018) \\
\hline Ajlon - Jordan & 2640 & & 56.09 & 49.9 & 6.08 & 5.48 & (Dweirj et al., 2017) \\
\hline Zarka - Jordan & 2360 & & 48.22 & 18.4 & 5.37 & 1.5 & (Dweirj et al., 2017) \\
\hline $\begin{array}{l}\text { Ma'an district } \\
\text { Sateh - Jordan }\end{array}$ & 2610 & & 51.18 & 45.1 & 5.61 & 4.95 & (Dweirj et al., 2017) \\
\hline Dabish - Jordan & 2540 & & 64.7 & 48.3 & 6.34 & 4.96 & (Dweirj et al., 2017) \\
\hline Turkey & $\begin{array}{c}2640- \\
2700 \\
\end{array}$ & & $\begin{array}{c}137.2- \\
187.4 \\
\end{array}$ & & $8.52-10.35$ & & $\begin{array}{c}\text { (Ozguven and Ozcelik, } \\
\text { 2013) }\end{array}$ \\
\hline $\begin{array}{c}\text { Austria } \\
\text { (different } \\
\text { locations) }\end{array}$ & & & $\begin{array}{l}3.75- \\
115.59\end{array}$ & $\begin{array}{l}3.32- \\
104.89\end{array}$ & & & (Bednarik et al., 2014) \\
\hline $\begin{array}{l}\text { Bratislava, } \\
\text { Slovakia }\end{array}$ & $2210-2600$ & & & & & & (Laho et al., 2010) \\
\hline
\end{tabular}

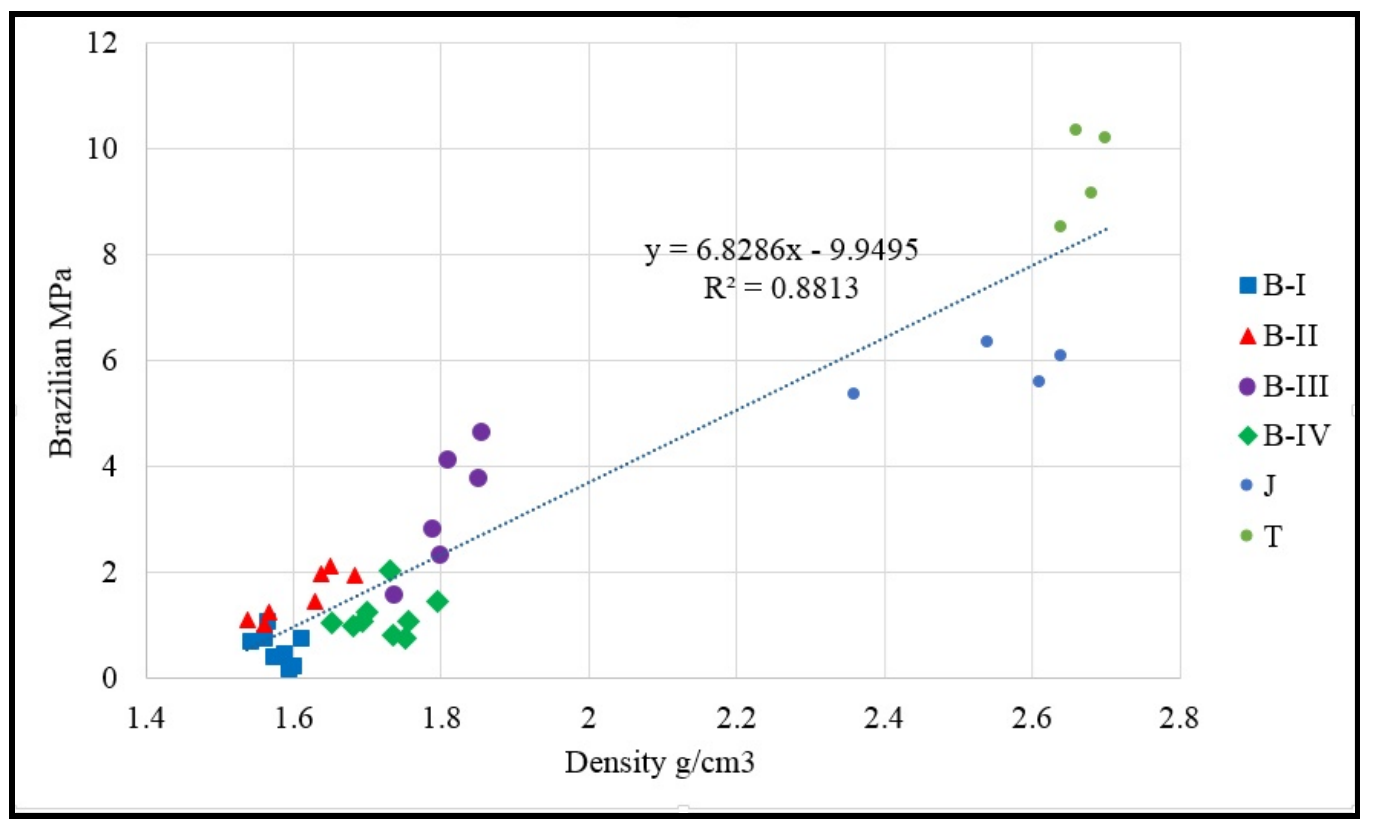

Fig. 11. Relationship between Brazilian strength and density of limestone, data sources: this study Budafok Types I-IV (B-I to B-IV), J-data from Jordan (Dweirj et al., 2017) and T-data from Turkey (Ozguven and Ozcelik, 2013).

The stability calculations resulted in a high difference between the maximum displacements in dry $6.45 \mathrm{~mm}$ and saturated $19.10 \mathrm{~mm}$ conditions and the safety factor also reduced significantly. The highly water sensitive material cause significant loss of safety factor. It predicts problems with the stability of the cellars because of the change in the water content of the rock mass. In reality, the whole rock mass cannot be saturated, but according to the on-site investigations locally, it can happen, which can cause local stability problems. 


\section{Conclusions}

The test results presented in this paper indicate that four lithotypes of porous limestone specimens, which were collected from the same cellar, have a wide range of physical parameters. The open porosity of the studied specimens is in between 16 to $30 \%$, having the highest value of the fine-grained lithotype (Type I) and the lowest one of the cross-laminated fine-to medium-grained type (Type IV). Comparing air dry and watersaturated strength parameters, the reduction in the strength exceeded 50\% for Type I and Type III lithologies. The lowest strength reduction due to water was measured at coarse-grained lithotype (Type II) where the loss is in the order of $14-16 \%$. The results suggest that water saturation has a less effect on US-wave velocities of porous limestone with large uniform pores (Type II). Relationships were outlined between the water absorption and open porosities that are different for each studied lithotype. Comparing the test results of the studied limestone with the previously published data on limestone indirect tensile strength and density, a good correlation was found. The stability of dry and water inundated cellars was calculated by using these parameters, considering that water significantly reduces the strength of this porous limestone and might lead to the collapse of the cellars.

\section{References}

Ademović, N. and Kurtović, A. (2018) Stone and mortar in bridges from the Ottoman period in Bosnia and Herzegovina, Journal of the Croatian Association of Civil Engineers, 70 (3), pp. 213-224. DOI:10.14256/JCE.2003.2017.

Al Heib, M., Duval, C., Watelet, J.-M. and Gombert, P. (2015) Back-analysis of the collapse of the Clamart chalk underground quarry - Paris (France), in: London: ICE Publishing, pp. 1525-1530.

ASTM D3967-16, Standard Test Method for Splitting Tensile Strength of Intact Rock Core Specimens, ASTM International, West Conshohocken, PA, 2016, www.astm.org

ASTM D7012-14e1, Standard Test Methods for Compressive Strength and Elastic Moduli of Intact Rock Core Specimens under Varying States of Stress and Temperatures, ASTM International, West Conshohocken, PA, 2014, www.astm.org

Aydan, Ö. and Ulusay, R. (2003) Geotechnical and geoenvironmental characteristics of man-made underground structures in Cappadocia, Turkey, Engineering Geology, 69 (3-4), pp. 245-272. DOI:10.1016/S00137952(02)00285-5.

Beck, K. and Al-Mukhtar, M. (2008) Formulation and characterisation of an appropriate lime-based mortar for use with a porous limestone, Environmental Geology, 56 (3-4), pp. 715-727. DOI:10.1007/s00254-0081299-8.

Bednarik, M., Moshammer, B., Heinrich, M., Holzer, R., Laho, M., Rabeder, J., Uhlir, C. and Unterwurzacher, M. (2014) Engineering geological properties of Leitha Limestone from historical quarries in Burgenland and Styria, Austria, Engineering Geology, 176, pp. 66-78. DOI:10.1016/j.enggeo.2014.04.005.

Cassar, JA. (2002) Deterioration of the Globigerina Limestone of the Maltese Islands, Geological Society, London, Special Publications, 205 (1), pp. 33-49. DOI:10.1144/GSL.SP.2002.205.01.04.

Ciotoli, G., Ferri, G., Nisio, S. and Succhiarelli, C. (2015) The underground cavities in the territory of Rome: typologies, distribution and sinkhole susceptibility, in: Italy Rome, pp. 433-439.

Čorko, D., Lovrenčić, D., Marić, B., Šteger, Z. and Leko, I. (2001) Remedial Works on the Foundation Rock of the "Old Bridge" in Mostar, in: Havar, Croatia, pp. 4.

De Kock, T., Van Stappen, J., Fronteau, G., Boone, M., De Boever, W., Dagrain, F., Silversmit, G., Vincze, L. and Cnudde, V. (2017) Laminar gypsum crust on lede stone: Microspatial characterisation and laboratory acid weathering, Talanta, 162, pp. 193-202. DOI:10.1016/j.talanta.2016.10.025.

Dweirj, M., Fraige, F., Alnawafleh, H. and Titi, A. (2017) Geotechnical Characterization of Jordanian Limestone, Geomaterials, 07 (01), pp. 1-12. DOI:10.4236/gm.2017.71001.

EN 13755:2008, Natural stone test methods. Determination of water absorption at atmospheric pressure, Comite Europeen de Normalisation, 2008

EN 14579:2004, Natural stone test methods. Determination of sound speed propagation, Comite Europeen de Normalisation, 2004

EN 1925:1999, Natural stone test methods. Determination of water absorption coefficient by capillarity, Comite Europeen de Normalisation, 1999

EN 1936:2006, Natural stone test methods: determination of real density and apparent density, and of total and open porosity, Comite Europeen de Normalisation, 2006

Fuentes, J. M., Gallego, E., García, A. I. and Ayuga, F. (2010) New uses for old traditional farm buildings: The case of the underground wine cellars in Spain, Land Use Policy, 27 (3), pp. 738-748. DOI:10.1016/j.landusepol.2009.10.002. 
Gálos, M., Kertész, P. and Kürti, I. (1981) Engineering geological problems of cellars and caverns under historical centres of towns, in: Subsurface Space. Elsevier, pp. 119-126.

Ghabezloo, S. and Pouya, A. (2006) Numerical modelling of the effect of weathering on the progressive failure of underground limestone mines, in: Van Cotthem, A., Charlier, R., Thimus, J.-F., and Tshibangu, J.-P. (eds.) Eurock 2006: Multiphysics Coupling and Long Term Behaviour in Rock Mechanics. Taylor \& Francis, pp. 233-240.

Ghafoori, M., Rastegarnia, A. and Lashkaripour, G. R. (2018) Estimation of static parameters based on dynamical and physical properties in limestone rocks, Journal of African Earth Sciences, 137, pp. $22-31$. DOI:10.1016/j.jafrearsci.2017.09.008.

Gibeaux, S., Vázquez, P., De Kock, T., Cnudde, V. and Thomachot-Schneider, C. (2018) Weathering assessment under X-ray tomography of building stones exposed to acid atmospheres at current pollution rate, Construction and Building Materials, 168, pp. 187-198. DOI:10.1016/j.conbuildmat.2018.02.120.

Görög, P., Hangodi, Á. and Török, Á. (2013) Stability analyses of underground structures cut into porous limestone, in: Paris, pp. 1707-1710.

Hassine, M. A., Beck, K., Brunetaud, X. and Al-Mukhtar, M. (2018) Use of electrical resistance measurement to assess the water saturation profile in porous limestones during capillary imbibition, Construction and Building Materials, 165, pp. 206-217. DOI:10.1016/j.conbuildmat.2017.12.238.

Hoek, E., Carranza-Torres, C. and Corkum, B. (2002) Hoek-Brown failure criterion - 2002 Edition, in: NARMSTAC Conference. Toronto,1, pp. 267-273.

Janič, P., Jadlovská, S., Zápach, J. and Koska, L. (2019) Modeling of underground mining processes in the environment of MATLAB / Simulink, Acta Montanistica Slovaca, 24 (1), pp. 44-52.

Kleb, B. and Vásárhelyi, B. (2003) Test results and empirical formulas of rock mechanical parameters of rhyolitic tuff samples from Eger's cellars, Acta Geologica Hungarica, 46 (3), pp. 301-312. DOI:10.1556/AGeol.46.2003.3.5.

Laho, M., Franzen, C., Holzer, R. and Mirwald, P. W. (2010) Pore and hygric properties of porous limestones: a case study from Bratislava, Slovakia, Geological Society, London, Special Publications, 333 (1), pp. 165174. DOI:10.1144/SP333.16.

Marasović, K., Perojević, S. and Margeta, J. (2014) Roman sewer of Dicletian's palace in Split, Journal of the Croatian Association of Civil Engineers. DOI:10.14256/JCE.966.2013.

Marschalko, M., Yilmaz, I., Bednárik, M. and Kubečka, K. (2012) Deformation of slopes as a cause of underground mining activities: three case studies from Ostrava-Karviná coal field (Czech Republic), Environmental Monitoring and Assessment, 184 (11), pp. 6709-6733. DOI:10.1007/s10661-011-2453-4.

Martínez-Martínez, J., Benavente, D., Gomez-Heras, M., Marco-Castaño, L. and García-del-Cura, M. Á. (2013) Non-linear decay of building stones during freeze-thaw weathering processes, Construction and Building Materials, 38, pp. 443-454. DOI:10.1016/j.conbuildmat.2012.07.059.

Modestou, S., Theodoridou, M., Fournari, R. and Ioannou, I. (2016) Physico-mechanical properties and durability performance of natural building and decorative carbonate stones from Cyprus, Geological Society, London, Special Publications, 416 (1), pp. 145-162. DOI:10.1144/SP416.3.

Ozguven, A. and Ozcelik, Y. (2013) Investigation of some property changes of natural building stones exposed to fire and high heat, Construction and Building Materials, 38, pp. 813-821. DOI:10.1016/j.conbuildmat.2012.09.072.

Pápay, Z. and Török, Á. (2017) Effect of Thermal and Freeze-thaw Stress on the Mechanical Properties of Porous Limestone, Periodica Polytechnica Civil Engineering, 62 (2), pp. 423-428. DOI:10.3311/PPci.11100.

Pappalardo, G., Mineo, S. and Monaco, C. (2016) Geotechnical characterisation of limestones employed for the reconstruction of a UNESCO world heritage Baroque monument in southeastern Sicily (Italy), Engineering Geology, 212, pp. 86-97. DOI:10.1016/j.enggeo.2016.08.004.

Polak, K., Różkowski, K. and Czaja, P. (2015) Causes and Effects of Uncontrolled Water Inrush into a Decommissioned Mine Shaft, Mine Water and the Environment, 35 (2), pp. 128-135. DOI:10.1007/s10230-015-0360-6.

Přikryl, R. (2013) Durability assessment of natural stone, Quarterly Journal of Engineering Geology and Hydrogeology, 46 (4), pp. 377-390. DOI:10.1144/qjegh2012-052.

Přrikryl, R. and Přikrylová, J. (2004) Leithakalk limestones in the Lednice-Valtice area (southest Moravia, Czech Republic): their occurrences and properties, in: Prague, pp. 149-156.

Rozgonyi, N. (2002) Durva mészkő viselkedése légköri szennyeződés hatására (Effect on air pollution on the behaviour of porous limestone). PhD Dissertation, Budapest University of Technology and Economics.

Scrivano, S., Gaggero, L. and Gisbert Aguilar, J. (2018) Micro-porosity and mincro-petrographic features influences on decay: Experimental data from four dimension stones, Construction and Building Materials, 173, pp. 342-349. DOI:10.1016/j.conbuildmat.2018.04.041. 
Siegesmund, S., Friedel, C.-H., Vogel, J., Mosch, S., Naumann, D., Peter, A. and Giesen, H. (2011) Stability assessment of sandstones from the St. Servatius Church in Quedlinburg (UNESCO's World Heritage Site, Germany), Environmental Earth Sciences, 63 (3), pp. 641-659. DOI:10.1007/s12665-010-0736-7.

Smeray, J., Mandin, D. and Chaumont, J. (2000) Annual variations of airborne fungal propagules in two wine cellars in French Jura, Cryptogamie Mycologie, 21 (3), pp. 163-169. DOI:10.1016/S01811584(00)80001-9.

Smith, B. J., Gómez-Heras, M. and Viles, H. A. (2010) Underlying issues on the selection, use and conservation of building limestone, Geological Society, London, Special Publications, 331 (1), pp. 1-11. DOI:10.1144/SP331.1.

Török, Á., Rozgonyi, N., Prikryl, R. and Prikrylová, J. (2004) Leithakalk: the ornamental and building stone of Central Europe, an overview, in: Czech Republic, pp. 89-93.

Török, Á., Siegesmund, S., Müller, C., Hüpers, A., Hoppert, M. and Weiss, T. (2007) Differences in texture, physical properties and microbiology of weathering crust and host rock: a case study of the porous limestone of Budapest (Hungary), Geological Society, London, Special Publications, 271 (1), pp. 261276. DOI:10.1144/GSL.SP.2007.271.01.25.

Török, Á. and Vásárhelyi, B. (2010) The influence of fabric and water content on selected rock mechanical parameters of travertine, examples from Hungary, Engineering Geology, 115 (3-4), pp. 237-245. DOI:10.1016/j.enggeo.2010.01.005.

Mocsár-Vámos, M., Görög, P. and Török, Á. (2015) Engineering geological characterisation of the host rocks of underground cellars in Avas hill, Northern Hungary, in: MG, Winter; DM, Smith; PJL, Eldred; DG, Toll (eds.) Geotechnical Engineering for Infrastructure and Development: XVI European Conference on Soil Mechanics and Geotechnical Engineering, ICE Publishing, London, pp. 2287-2292.

Vásárhelyi, B. (2005) Statistical Analysis of the Influence of Water Content on the Strength of the Miocene Limestone, Rock Mechanics and Rock Engineering, 38 (1), pp. 69-76. DOI:10.1007/s00603-004-0034-3.

Vlastelica, G., Miščević, P. and Pavić, N. (2017) Testing the shear strength of soft rock at different stages of laboratory simulated weathering, Journal of the Croatian Association of Civil Engineers, 68 (12), pp. 955-965. DOI:10.14256/JCE.1878.2016.

Zenah, J., Török, Á., Rehány, N. and Görög, P. (2019) Investigation of the effect of construction activities to underground cavities cut into porous limestone, in: Omiš - Split, Croatia, pp. 453-458.

Zhang, K.-J., Li, Q.-H., Yan, L.-L., Zeng, L., Lu, L., Zhang, Y.-X., Hui, J., Jin, X. and Tang, X.-C. (2017) Geochemistry of limestones deposited in various plate tectonic settings, Earth-Science Reviews, 167, pp. 27-46. DOI:10.1016/j.earscirev.2017.02.003. 